MICHAE SZEWCZYK

\title{
Najwyższe zwierzchnictwo Prezydenta Rzeczypospolitej Polskiej nad siłami zbrojnymi w świetle konstytucji z 2 kwietnia 1997 roku
}

Wydawnictwo Sejmowe, Warszawa 2018, s. 360

\author{
Michał Szewczyk, The supreme command of the President of the Republic of \\ Poland over the armed forces as of the Constitution of 2 April 1997
}

\begin{abstract}
The author discusses the important issue of the supreme command of the armed forces vested in the President of the Republic of Poland, as established by the Polish Constitution. General principles of the civil and democratic control over the armed forces are presented, the command classification, including the presidential system (the United States), the semi-presidential system (the French Republic) and the rationalized parliamentary-cabinet system (the Republic of Italy), as well as history thereof. The key element is the presentation of the President's command of the armed forces as of the Polish Constitution and the detailed analysis of the President's competences. Importantly, the systemic practice is also presented, referring to the period when the office of the President was exercised by Aleksander Kwaśniewski, Lech Kaczyński, Bronisław Komorowski and Andrzej Duda. The author also reflects on the relevant events from Lech Wałęsa's presidency. A critical opinion on the legal system in this sphere and important de lege ferenda conclusions are presented - these shall be addressed not only to scientists, but most of all to representatives of state authorities.
\end{abstract}

Slowa kluczowe: Prezydent RP, zwierzchnictwo nad siłami zbrojnymi, demokratyczna kontrola nad armia, Polska, Stany Zjednoczone, Francja, Włochy

Key words: President of the Republic of Poland, command of the armed forces, democratic control of the army, Poland, the United States, France, Italy

Recenzowana książka — niewątpliwie — dotyczy ważnego problemu ustrojowego. Pośród zagadnień dotyczących obronności i bezpieczeństwa istotne znaczenie ma stosunek prezydenta do sił zbrojnych. Od zarania instytucji państwa — jak zauważył autor — władca był naczelnym wodzem armii, dysponującym prawem do wypowiadania wojen i prowadzenia działań zbrojnych. Mimo że na skutek wielowiekowej ewolucji ustrojowej monarchiczne i republikańskie głowy państwa traciły stopniowo kolejne uprawnienia w materii militarnej, po dzień dzisiejszy w zdecydowanej większości państw demokratycznych sprawują one, rozmaicie rozumiane, naczelne dowództwo lub zwierzchnictwo nad armią. Na mocy art. 134 ust. 1 Konstytucji Rzeczypospolitej Polskiej z 2 kwietnia 1997 r. prezydent pełni funkcję najwyższego zwierzchnika sił zbrojnych. Jednak pomimo upływu ponad dwudziestu lat od wejścia w życie konstytucji, stan badań na temat wymienionej roli ustrojowej prezydenta w nauce prawa konstytucyjnego wciąż nie jest zadawalający, zwłaszcza w odniesieniu do wydarzeń z historii III Rzeczypospolitej, także stosunkowo niedawnych. Stąd zapełnienie tej luki badawczej, poprzez ustalenie istoty i treści prezydenckiej funkcji z art. 134 ust. 1, zostało określone przez autora jako podstawowy cel pracy. Na potrzeby prowadzonych 
w niej rozważań przyjął on, że środkami służącymi do sprawowania zwierzchnictwa głowy państwa nad armią są nie tylko uprawnienia tego podmiotu wiążące się ściśle ze sprawami sił zbrojnych, ale także inne kompetencje skorelowane z problematyką obronności i bezpieczeństwa państwa. Drugim założeniem badawczym była próba krytycznej oceny obowiązujących obecnie regulacji normatywnych wiążących się ze statusem prezydenta wobec wojska, połączona ze zgłoszeniem postulatów de lege ferenda $\mathrm{w}$ takim zakresie, w jakim uznał to za konieczne (s. 7-8).

W rozdz. I przedstawiona została zasada cywilnej i demokratycznej kontroli nad siłami zbrojnymi (s. 15). Autor zaprezentował istotę oraz modele cywilnej i demokratycznej kontroli nad armią (s. 19), a także prawnomiędzynarodowe standardy w zakresie cywilnego i demokratycznego zwierzchnictwa nad siłami zbrojnymi (s. 24). Szczegółowo odniósł się do warunków, których spełnienie jest konieczne do posiadania przez państwo efektywnej cywilnej i demokratycznej kontroli nad wojskiem (s. 29). Dotyczy to precyzyjnego podziału kompetencji w sprawach obronności i bezpieczeństwa między konstytucyjne organy państwowe (s. 35), rozdzielenia dowodzenia od kierowania wojskiem (s. 44) oraz zagwarantowania neutralności politycznej sił zbrojnych (s. 45).

W rozdz. II została ukazana pozycja głowy państwa wobec sił zbrojnych w wybranych modelach ustrojowych. Uwzględnione zostały: system prezydencki na przykładzie Stanów Zjednoczonych Ameryki (s. 53), system semiprezydencki na przykładzie Republiki Francuskiej (s. 61) oraz zracjonalizowany system parlamentarno-gabinetowy na przykładzie Republiki Włoskiej (s. 69).

W rozdz. III (,Stosunek głowy państwa do sił zbrojnych w polskiej tradycji ustrojowej od 1918 r.") autor przedstawił rolę głowy państwa w okresie II RP i w Polsce Ludowej (s. 76) oraz w okresie transformacji ustrojowej lat 1989-1997 (s. 84). Uwzględnił okresy zarówno przed wejściem (s. 84), jak i po wejściu w życie małej konstytucji z 1992 r. (s. 102).

Kluczowe znaczenie ma rozdział IV („Ogólna charakterystyka prezydenckiego najwyższego zwierzchnictwa nad siłami zbrojnymi pod rządami konstytucji z 2 kwietnia 1997 r.”). Szczególnie istotne są tu rozważania na temat statusu głowy państwa wobec wojska w kontekście zasad cywilnej i demokratycznej kontroli nad siłami zbrojnymi oraz neutralności politycznej armii (s. 144). Autor przedstawił też sposób sprawowania zwierzchnictwa nad wojskiem w czasie pokoju i wojny (s. 155). Podjął próbę zdefiniowania kategorii zwierzchnictwa, kierowania i dowodzenia (s. 168), a także odniósł się do zakresu i kształtu najwyższego zwierzchnictwa nad armią w sytuacji sojuszniczej operacji obronnej NATO na terytorium Rzeczypospolitej Polskiej (s.170). Istotne są tu rozważania dotyczące Rady Bezpieczeństwa Narodowego (s. 171) i Biura Bezpieczeństwa Narodowego (s. 178).

W rozdz. V („Kompetencje najwyższego zwierzchnika sił zbrojnych”) autor dokonał analizy uprawnień specjalnych najwyższego zwierzchnika sił zbrojnych, z których może on korzystać zarówno w czasie pokoju, jak i w czasie wojny (s. 187), jak i uprawnień specjalnych najwyższego zwierzchnika sił zbrojnych, z których może on 
korzystać tylko w czasie wojny (s. 213). W polu zainteresowania autora znalazły się też uprawnienia specjalne najwyższego zwierzchnika sił zbrojnych związane ze szczególnymi zagrożeniami dla państwa innymi niż czas wojny (s. 223). Uwzględnione zostały tu: stan wojny i zawarcia pokoju (s. 223), powszechna i częściowa mobilizacja oraz użycie sił zbrojnych do obrony Rzeczypospolitej Polskiej (s. 233), stan wojenny (s. 241), stan wyjątkowy (s. 251), ustawa o policji (s. 259) oraz ustawa o działaniach antyterrorystycznych (s. 262).

W rozdz. VI zatytułowanym „Praktyka ustrojowa” autor dokonał analizy realizacji funkcji zwierzchnika sił zbrojnych przez kolejnych prezydentów: Aleksandra Kwaśniewskiego (s. 266), Lecha Kaczyńskiego (s. 278), Bronisława Komorowskiego (s. 291) i Andrzeja Dudę (s. 301).

Układ pracy można uznać za spójny i logiczny. Autor wyszedł od ogólnej prezentacji zasady cywilnej i demokratycznej kontroli nad siłami zbrojnymi (rozdz. I), aby następnie poddać analizie doświadczenia prawnoporównawcze (rozdz. II ), jak i historyczne (rozdz. III). Stworzyło do dobry punkt odniesienia dla ukazania zwierzchnictwa prezydenta na siłami zbrojnymi pod rządami Konstytucji RP (rozdz. IV) oraz szczegółowej analizy kompetencji najwyższego zwierzchnika sił zbrojnych (rozdz. V). Logicznym uzupełnieniem była analiza praktyki ustrojowej w tym obszarze (rozdz. VI).

Patrząc na strukturę pracy można się jedynie zastanawiać, czy trafne było umieszczenie w jednym podrozdziale roli głowy państwa w sprawach wojskowych w II Rzeczypospolitej i w Polsce Ludowej (s. 76). Ustrój polityczny w obu okresach tak istotnie się różnił, że analiza powinna następować w oddzielnych podrozdziałach. Analizując strukturę rozdziału $\mathrm{V}$, można odnotować pewne załamanie się logiczne konstrukcji podrozdziału 4. Autor najpierw idzie ujęciem instytucjonalnym (punkty 4.1.-4.4.), a później przechodzi na wymienienie nazw ustaw, a przecież przedmiotem analizy nie są ustawy o policji (4.5.) i o działaniach terrorystycznych (4.6.), a sytuacje (stany) w nich uregulowane, niosące uprawnienia najwyższego zwierzchnika sił zbrojnych związane ze szczególnymi zagrożeniami dla państwa innymi niż czas wojny. Należałoby je wyartykułować bądź indywidualnie, bądź w ramach pewnych grup.

Dobór państw wykorzystanych w analizie prawnoporównawczej (rozdz. II) jest logiczny w tym sensie, że uwzględnia podstawowe modele ustrojowe: system prezydencki, system semiprezydencki oraz zracjonalizowany system parlamentarno-gabinetowy. Należy wszakże odnotować, że autor ograniczył się do państw o ugruntowanej demokracji, stabilnym podziale władzy oraz utrwalonej kulturze politycznej i prawnej. W wyniku tego faktyczny kontekst porównawczy został ograniczony. Byłoby inaczej, gdyby autor sięgnął też do państw (państwa), gdzie powyższe cechy nie występuja, bądź ich realizacja napotyka na istotne trudności w praktyce ustrojowej. Takim państwem godnym uwzględnienia mogłaby być np. Federacja Rosyjska, gdzie też formalnie mamy do czynienia z systemem semiprezydenckim, ale realizowanym w zupełnie innym kontekście kultury politycznej i prawnej oraz tradycji ustrojowej. Uwzględnienie takiego modelu otwierałoby pole dla bardziej pogłębionej analizy uwarunkowań faktycznej realizacji cywilnej kontroli nad armia. Dałoby to asumpt do uka- 
zania, jak znacząco różni się cywilna i demokratyczna kontrola nad siłami zbrojnymi w państwach o istotnie zróżnicowanej praktyce ustrojowej i odmienności w postrzeganiu reguł demokracji.

Natomiast gdy autor poddał analizie praktykę ustrojowa, to zawężenie rozważań do czterech prezydentów (A. Kwaśniewski, L. Kaczyński, B. Komorowski, A. Duda) było logiczne w tym sensie, że autor zajmuje się najwyższym zwierzchnictwem prezydenta nad siłami zbrojnymi pod rządami konstytucji RP z 1997 r. Skoro jednak autor zdecydował się ukazać stosunek głowy państwa do sił zbrojnych również w ujęciu historycznym (rozdz. III), to nie byłoby błędem uwzględnienie praktyki ustrojowej również w latach 1990-1995, zwłaszcza że okres prezydentury Lecha Wałęsy ujawnił istotne problemy ustrojowe w tym zakresie, a Konstytucja RP była próbą wykorzystania doświadczeń, które przyniósł ten okres. Autor zresztą cząstkowo nawiązał do tych doświadczeń wskazując np. że L. Wałęsa, mimo braku wyraźnych podstaw normatywnych, dominował w państwie w materii jego obronności i bezpieczeństwa pod rząami zmienionej nowelą kwietniową konstytucji z 1952 r. i małej konstytucji z 1992 r. (s. 313-314).

Michał Szewczyk wskazał, że „przyznanie głowie państwa funkcji z art. 134 ust. 1 konstytucji jest najbardziej symbolicznym, chociaż w rzeczywistości niezbyt doniosłym, wyrazem podporządkowania armii demokratycznie legitymizowanym cywilnym organom konstytucyjnym, które sprawują nad nią kierownictwo — tak bowiem należy poprawnie rozumieć treść zasady cywilnej i demokratycznej kontroli nad siłami zbrojnymi” (s. 314). Użycie słów „niezbyt doniosłym” może jednak rodzić uwagi i zapytania. Nie sposób sądzić, że autor w ten sposób chciałby deprecjonować znaczenie cywilnej i demokratycznej kontroli nad siłami zbrojnymi. Jeśli natomiast ocenia, że wykonywanie tej kompetencji w niewystarczającym stopniu spełnia tu zakładany cel, to sformułowana ocena wydaje się niezbyt fortunna.

Pewnego doprecyzowania intencji wymagałaby też myśl, nawiązująca do zdarzeń z okresu prezydenta L. Wałęsy, że ,głowa państwa powinna być podstawowym filarem podległości armii demokratycznemu kierownictwu o charakterze cywilnym, a nie osoba, która wskazane pryncypia będzie podważać" (s. 314). Najprawdopodobniej mamy tu do czynienia z aluzyjnym nawiązaniem do „obiadu drawskiego", ale tam nie chodziło przecież o podważenie roli prezydenta jako uosobienia „demokratycznego kierownictwa", a o zakwestionowanie pozycji cywilnego ministra w relacjach z kierownictwem armii.

Autor trafnie zwrócił uwagę, że ustrojowa rola prezydenta w zakresie zwierzchnictwa nad siłami zbrojnymi ma charakter bierny, tzn. organ ten nie ma prawa do dowodzenia i/lub kierowania wojskiem, przynależnego choćby prezydentowi Stanów Zjednoczonych. W rezultacie pozbawiony jest on kompetencji do wydawania żołnierzom rozkazów. Jedynym cywilnym organem konstytucyjnym, którego decyzje kierowane do żołnierzy mają moc rozkazów, jest minister obrony narodowej. „Uzasadnieniem [jak napisał M. Szewczyk] tezy o biernym charakterze prezydenckiego zwierzchnictwa nad wojskiem jest niewyposażenie tego organu w stosowne uprawnie- 
nia kierowniczo-dowódcze wobec armii w żadnym przepisie prawa powszechnie obowiązującego. $Z$ kolei wywodzenie omawianej kompetencji tylko z treści art. 134 ust. 1 ustawy zasadniczej byłoby niezgodne z konstytucyjną zasadą legalizmu" (s. 315).

Autor konsekwentnie w książce broni poglądu, w myśl którego prezydent może pełnić swoją funkcję wobec sił zbrojnych tylko na podstawie wyraźnie przyznanych mu na poziomie konstytucyjnym i ustawowym kompetencji. „Jedynie jako wyjątek, niepodlegający wykładni rozszerzającej, uznać należy, że status najwyższego zwierzchnika sił zbrojnych, a także gwaranta ciagłości władzy państwowej, strażnika suwerenności, niepodległości i bezpieczeństwa państwa oraz nienaruszalności i niepodzielności jego terytorium legitymuje głowę państwa do negatywnego (odmownego) odnoszenia się do składanych jej przez inne organy państwowe wniosków. Ponadto może stać się tak tylko wtedy, gdy jej uwzględnienie oznaczałoby obiektywne zagrożenie dla jakiejś z wymienionych wartości konstytucyjnych, których ma ona strzec. W rezultacie art. 126 ust. 1 i 2, art. 130 i art. 134 ust. 1 konstytucji mają wymiar kompetencyjny jedynie w tak określonym zakresie" (s. 315).

Autor podkreślił, że ,w czasie pokoju prezydent sprawuje zwierzchnictwo nad siłami zbrojnymi za pośrednictwem Ministra Obrony Narodowej, przy czym de lege lata, inaczej niż w poprzednich okresach w historii konstytucjonalizmu III Rzeczypospolitej, nie ma on formalnie żadnego wpływu na obsadę takie stanowiska rządowego. Tym samym mamy tutaj do czynienia z ewidentnym i bezprecedensowym ograniczeniem możliwości głowy państwa wobec wojska, będącym — jak się wydaje - wyraźną odpowiedzią na ekstensywną wykładnię omawianej roli ustrojowej za czasów prezydenta L. Wałęsy” (s. 316). Mówienie o „ewidentnym i bezprecedensowym” ograniczeniu możliwości głowy państwa wobec wojska wydaje się przesadne. Autor nawiązał tu najwidoczniej do przewidzianej pod rządami małej konstytucji z 1992 r. kompetencji prezydenta do opiniowania kandydatów na niektóre stanowiska w rządzie, w tym wypadku chodzi o ministra obrony narodowej. Skoro była to w założeniu ustrojowym opinia niewiążąca, trudno twierdzić, że otwierała ona jakieś szczególne możliwości prezydenta wobec wojska. Prawdą jest natomiast to, że interpretacja tego — w założeniu skromnego - uprawnienia przez prezydenta L. Wałęsę, pod wpływem ocen prof. Lecha Falandysza, w kierunku teorii „resortów prezydenckich”, wyłączonych w istotnym stopniu spod kontroli rządu, w sposób zasadniczy podważyła reguły systemu parlamentarno-gabinetowego. Otwierała bowiem w istocie konstrukcję „dwuwładzy", osłabiającą odpowiedzialność polityczną rządu i premiera za obszar obronności narodowej. Jeśli więc coś tu było „ewidentne i bezprecedensowe”, to raczej próba ograniczenia faktycznej władzy rządu (a konsekwencji także parlamentarnej większości rządowej) w obszarze tzw. „,resortów siłowych”. Stan taki musiał być krytycznie oceniany i doprowadził do jego skorygowania w ramach Konstytucji RP z 2 kwietnia 1997 r.

Dokonana przez M. Szewczyka analiza regulacji normatywnych i praktyki ustrojowej doprowadziła go do wyartykułowania tezy, że w czasie pokoju to Rada Ministrów, a nie głowa państwa ma realny prymat w sprawach wojskowych, a szerzej - 
obronności i bezpieczeństwa państwa. W tym okresie prezydent jest $\mathrm{w}$ stanie realizować swe postulaty w tej materii, za pomoca przyznanych mu kompetencji, jak i działań niewładczych, tylko pod warunkiem zgodnej współpracy z rządem, premierem oraz ministrem obrony narodowej. W polskiej rzeczywistości ustrojowej z taką sytuacją mamy do czynienia zasadniczo wtedy, gdy prezydenci sprawują swój urząd w czasie, gdy rząd tworzony jest przez ich własne, bezpośrednie zaplecze partyjne. Wówczas, zwłaszcza przy słabej pozycji politycznej premiera, nieposiadającego niezbędnej wiedzy i doświadczenia w sprawach wojskowych, cechujący się takimi przymiotami najwyższy zwierzchnik sił zbrojnych jest w stanie faktycznie dominować w tym obszarze spraw państwowych. „Poniekąd z tego typu kazusem mieliśmy do czynienia w czasie prezydentury B. Komorowskiego i premierostwa E. Kopacz. Dotychczasowe doświadczenia prezydentury A. Dudy pokazuja, że słaba pozycja polityczna głowy państwa, a także brak wiedzy i doświadczenia w materii militarnej mogą prowadzić do znacznego osłabienia realnego wymiaru funkcji z art. 134 ust. 1 konstytucji nawet wtedy, gdy rząd tworzony jest przez bezpośrednie zaplecze partyjne prezydenta" (s. 318-319).

Te rozważania autora godne są szczególnej uwagi, bo wskazuja, że o faktycznym kształcie zwierzchnictwa Prezydenta Rzeczypospolitej Polskiej nad siłami zbrojnymi przesądza nie tylko konstrukcja ustrojowa, zawarta w Konstytucji RP, ale też układ sił politycznych na linii rząd - głowa państwa. Oryginalne wydaje się tu zwłaszcza zwrócenie uwagi na fakt, że napięcia w układzie dualizmu egzekutywy w obszarze obronności mogą się zdarzyć nie tylko w sytuacji kohabitacji prezydenta i rządu wywodzących się z innych opcji politycznych (jak to było w okresie 1997-2000), ale również w sytuacji, gdy oba te stanowiska znajdują się pod kontrolą tej samej siły politycznej. Istotny czynnikiem staje się wówczas faktyczna siła polityczna prezydenta i premiera, która może otwierać drogę do silniejszej pozycji prezydenta w zakresie realizacji zwierzchnictwa nad siłami zbrojnymi niż ta, która rysuje się w świetle odczytania postanowień Konstytucji RP w tym zakresie.

Autor dokonał krytycznej analizy aktualnego stanu prawnego związanego pośrednio i bezpośrednio z prezydencką rolą ustrojowa, określoną w art. 134 ust. 1 konstytucji. Uważa on, że „obecne rozwiązania normatywne zasługują na zasadniczo niską ocenę, m.in. z uwagi na ich częstą wzajemną niespójność, trudności z ich wykładnią czy też niezgodność z konstytucyjną dyrektywą spójności działania instytucji publicznych. Ponadto nierzadko odnotowujemy po prostu brak postanowień normatywnych traktujących niekiedy o fundamentalnych z punktu widzenia samego bytu państwa polskiego kwestiach. Wymownym tego przykładem są luki prawne dotyczące instytucji NDSZ i kierowania siłami zbrojnymi w czasie wojny" (s. 320). Wskazuje on, że zachodzi konieczność , ujednolicenia terminologii konstytucyjnej odnoszącej się do problematyki obronności i bezpieczeństwa zawartej odpowiednio w art. 5 traktującym o zadaniach państwa jako całości, art. 26 ust. 1 definiującym cele działalności sił zbrojnych oraz art. 126 ust. 2 i art. 130 określającymi zadania prezydenta" (s. 320-321). Sugeruje też, że warto „dostosować konstytucyjny katalog zadań wojska do wyzwań 
współczesności, wiążących się z coraz szerszym wykorzystaniem tej formacji do zadań z zakresu bezpieczeństwa wewnętrznego" (s. 321). M. Szewczyk postuluje ponadto „dekonstytucjonalizację instytucji Szefa Sztabu Generalnego oraz rodzajów sił zbrojnych, co umożliwi bardziej swobodne kształtowanie systemu dowodzenia polskim wojskiem" (s. 321). Proponuje też zmianę proklamacji czasu wojny z „konieczności obrony państwa” na „zbrojną napaść na terytorium RP” (s. 322).

Te i wiele innych postulatów de lege ferenda i de lege fundamentali ferenda $\mathrm{z}$ pewnością zasługują na zainteresowanie przedstawicieli władzy wykonawczej i władzy ustawodawczej, odpowiedzialnych za kształtowanie systemu prawnego w tej dziedzinie.

Podejmując próbę generalnego określenia prezydenckiego zwierzchnictwa nad siłami zbrojnymi w okresie obowiązywania ustawy zasadniczej z $1997 \mathrm{r}$. autor wskazał, że „absolutnie nieuprawnione wydaje się określenie tej funkcji głowy państwa mianem jedynie symbolicznej czy też formalnej” (s. 319). M. Szewczyk zauważył zarazem, że ,z uwagi na bierny charakter polskie zwierzchnictwo nad siłami zbrojnymi ma niewątpliwie słabszy wymiar niż naczelne dowództwo nad siłami zbrojnymi sprawowane przez prezydenta Stanów Zjednoczonych Ameryki, stojącego na szczycie amerykańskiej hierarchii dowodzenia i kierowania wojskiem. Swój prymat amerykański prezydent wywodzi $\mathrm{w}$ znacznej mierze $\mathrm{z}$ samej istoty systemu prezydenckiego, w którym nie funkcjonuje instytucja premiera” (s. 319). Wskazał też, że z ,punktu widzenia kompetencji specjalnych polskiej głowy państwa związanych z materią militarna, ocenianych z uwzględnieniem praktyki ustrojowej, najbardziej zasadne wydaje się wskazanie, że jej status wobec wojska jest słabszy niż pozycja Prezydenta Republiki Francuskiej w semiprezydenckim modelu ustrojowym, lecz silniejszy niż status Prezydenta Republiki Włoskiej w zracjonalizowanym, parlamentarno-gabinetowym systemie rządów. Tym samym pozycja Prezydenta RP jako najwyższego zwierzchnika armii poniekąd odzwierciedla zasadniczą niejednoznaczność w określeniu jego pozycji ustrojowej pod rządami konstytucji z 1997 r. Cechuje ją zasadnicza aprobata ustrojodawcy dla rozwiązań znanych zracjonalizowanemu, parlamentarno-gabinetowemu modelowi ustrojowemu, z zachowaniem jednak pewnych elementów prezydencjalizmu, których przykładem jest szczególna pozycja prezydenta w sprawach obronności i bezpieczeństwa państwa" (s. 319-320).

Ta kluczowa dla pracy teza wydaje się trafna. Można jedynie wskazać, że sygnalizuje ona istotę analizowanego modelu ustrojowego państwa niezawężoną bynajmniej tylko do kwestii zwierzchnictwa prezydenta nad siłami zbrojnymi. Zasadniczą sprawa jest bowiem kwestia prawidłowości jego usytuowania w systemie politycznym RP. Z jednej strony bezpośredni wybór prezydenta przez naród i związany z tym szczególny mandat powinien przemawiać za silniejszym jego usytuowaniem w systemie ustrojowym, w kierunku charakterystycznym dla modelu semiprezydenckiego. Z drugiej strony zachowanie reguł systemu parlamentarno-gabinetowego, również w jego zracjonalizowanej formie, przemawia za usytuowaniem punktu ciężkości w ramach władzy wykonawczej na rządzie i premierze. Ten dylemat nie tylko rzutuje na stosowanie Konstytucji RP (również w obszarze problematyki zwierzchnictwa prezydenta 
nad silami zbrojnymi), ale można go zaliczyć do podstawowych problemów, które należy rozważyć, gdyby doszło do zmiany lub uchwalenia nowej konstytucji. Wówczas to przyjdzie zapewne rozstrzygać, czy poprzestać na aktualnym, biernym modelu zwierzchnictwa, czy też próbować nadać temu zwierzchnictwu bardziej znaczącą w państwowym systemie decyzyjnym formę.

Zasadniczym walorem książki jest to, że autor nie ograniczył się do egzegezy prawnoustrojowej konstrukcji kompetencyjnej Prezydenta RP w zakresie zwierzchnictwa nad siłami zbrojnymi, ale podjął się szczegółowej analizy rozwiązań ustawodawczych, a ponadto w szerokim zakresie sięgnął do praktyki ustrojowej. Swoje rozważania oparł na obszernym uwzględnieniu literatury przedmiotu, a także twórczo wykorzystał elementy prawnoporównawcze. Zaprezentował wyważone sądy w kwestiach, które obiektywnie nastręczają poważne problemy interpretacyjne. Praca cechuje się czytelnym, a zarazem precyzyjnym językiem. W wyniku tego powstał wiarygodny obraz instytucji zwierzchnictwa Prezydenta RP nad siłami zbrojnymi, ukazujący szereg niedostatków obowiązującej regulacji. Przemyślenia M. Szewczyka, a zwłaszcza wnioski de lege ferenda i de lege fundamentali ferenda zasługują na wnikliwą analizę nie tylko środowisk naukowych, ale nade wszystko odpowiednich organów państwowych. Niewatpliwie mamy tu bowiem do czynienia z ważnym obszarem działań państwowych, którego prawidłowa, precyzyjna i wolna od luk regulacja ma istotne znaczenie nie tylko dla ładu ustrojowego i pewności prawnej, ale też dla bezpieczeństwa państwa.

Jerzy Jaskiernia*

* Prof. dr hab. Jerzy Jaskiernia, Uniwersytet Jana Kochanowskiego w Kielcach, jerzyj@hot.pl 